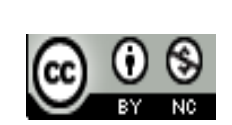

Jurnal Pendidikan Bahasa dan Sastra Indonesia is licensed under A Creative Commons Attribution-Non Commercial 4.0 International License

\title{
Analisis Kesalahan Penggunaan Pedoman Ejaan Bahasa Indonesia (PUEBI) Pada Tugas Makalah dan Laporan Praktikum Mahasiswa IT Telkom Purwokerto
}

\author{
M. Lukman Leksono \\ Institut Teknologi Telkom Purwokerto \\ E-mail:lukman@ittelkom-pwt.ac.id
}

\begin{abstract}
Abstrak. Penelitian ini bertujuan untuk mendeskripsikan: (1) bentuk kesalahan penggunaan pedoman ejaan bahasa Indonesia (PUEBI) yang meliputi kesalahan huruf, kata, tanda baca, kata serapan, diksi, kalimat, dan paragraf; (2) faktor penyebab terjadinya kesalahan dalam makalah dan laporan praktikum mahasiswa IT Telkom Purwokerto; dan (3) upaya yang dilakukan untuk mengatasi kesalahan penggunaan pedoman ejaan bahasa Indonesia (PUEBI). Penelitian ini merupakan penelitian deskriptif kualitatif pendekatan analisis isi dengan sampel makalah dan laporan praktikum mahamahasiswa IT Telkom Purwokerto yang berjumlah 10. Hasil penelitian ini adalah sebagai berikut. Pertama, bentuk kesalahan berbahasa yang ditemukan dalam makalah dan laporan praktikum mahasiswa IT Telkom Purwokerto meliputi: kesalahan huruf, kata, tanda baca, kata serapan, diksi, kalimat, dan paragraf. Kedua, faktor penyebab kesalahan penggunaan pedoman ejaan bahasa Indonesia (PUEBI) dalam makalah dan laporan praktikum disebabkan oleh empat faktor, antara lain: penguasaan kaidah kebahasaan mahasiswa kurang, ketidaktelitian dalam menulis, kurangnya motivasi menulis, dan kurangnya kosakata mahasiswa. Ketiga, upaya yang dilakukan untuk mengatasi kesalahan penggunaan pedoman ejaan bahasa Indonesia (PUEBI) dalam makalah dan laporan praktikum, antara lain: melaksanakan pembelajaran menulis dengan pendekatan proses, meningkatkan penguasaan kaidah bahasa mahasiswa dengan membaca, dan memperbanyak latihan menulis.
\end{abstract}

Kata Kunci: kesalahan berbahasa; bentuk kesalahan; laporan hasil observasi; penyebab kesalahan

\section{PENDAHULUAN}

Kegiatan menulis di lingkungan kampus merupakan salah satu bagian dari keterampilan berbahasa yang perlu mendapat perhatian lebih. Hal ini merupakan kenyataan bahwa kegiatan menulis merupakan kegiatan yang bersifat mendasar. Menulis merupakan salah satu sarana untuk menuangkan ide gagasan. Kegiatan menuangkan ide dalam bentuk tulisan ini memerlukan pemahaman tentang kemampuan kebahasaan. Mahasiswa dalam memahami ilmu bahasa Indonesia, mereka harus bisa menguasi faktor-faktor komunikasi. Pada saat berkomunikasi, baik lisan maupun tulisan, mereka harus menggunakan keterampilan berbahasa yang telah dimiliki, meskipun setiap orang memiliki tingkatan atau kualitas yang berbeda-beda. Orang yang memiliki keterampilan berbahasa secara optimal, setiap tujuan komunikasinya akan dapat dengan mudah tercapai. Sementara itu, bagi orang yang memiliki tingkat keterampilan bahasa lemah, ketika melakukan komunikasi bukan tujuannya yang akan tercapai, tetapi justru akan sering timbul kesalahpahaman antara penutur dan mitra tuturnya.
Ada empat macam keterampilan berbahasa yang harus dikuasai oleh mahasiswa, yaitu: (1) keterampilan menyimak, (2) keterampilan berbicara, (3) keterampilan membaca, dan (4) keterampilan menulis. Kegiatan menulis dipengaruhi oleh keterampilan produktif, yaitu aspek berbicara maupun keterampilan reseptif yang terdiri dari aspek membaca dan menyimak serta pemahaman kosakata, diksi, keefektifan kalimat, penggunaan ejaan dan tanda baca. Keterampilan menulis merupakan kemampuan yang paling sulit dan paling akhir dikuasai. Hal tersebut sesuai dengan pernyataan Javed, Juan, dan Nazli (2013: 130) bahwa kemampuan menulis lebih sulit dibandingkan dengan kemampuan berbahasa lainnya. Hal ini disebabkan kemampuan menulis menghendaki penguasaan berbagai unsur kebahasaan dan unsur di luar bahasa itu sendiri yang akan menjadi karangan. Baik unsur bahasa maupun unsur isi haruslah terjalin sedemikian rupa sehingga menghasilkan karangan yang runtut dan padu.

Bahasa Indonesia ragam tulis digunakan baik dalam tulisan tidak resmi maupun resmi. Pada tulisan resmi, seperti laporan, penggunaan kalimat yang teratur dan lengkap serta penggunaan ejaan yang cermat sangat diperlukan. 
Keteraturan dan kelengkapan kalimat serta ejaan dalam sebuah tulisan dapat mengungkapkan gagasan atau pikiran yang jelas. Kejelasan gagasan dalam sebuah tulisan akan memudahkan pembaca memahami tulisan itu.

Pada Satuan Acara Pengajaran (SAP) dan silabus, baik PTN maupun PTS, mahasiswa dituntut untuk terampil menulis karya ilmiah. Adanya kompetensi menulis menulis akan membuat mahasiswa menjadi terlatih untuk menuangkan ide/pikiran dan informasi dalam wacana tulis berbentuk teks laporan, karya ilmiah, proposal, atau makalah. Tidaklah sedikit mahasiswa yang masih merasa bingung dalam menulis makalah dan laporan praktikum khususnya penggunaan ejaan yang baik dan benar. Sementara itu, pada proses menulis terdapat aturan dan kaidah baku yang harus dikuasai mahasiswa, yaitu EBI (Ejaan Bahasa Indonesia). PUEBI (pedoman umum ejaan bahasa Indonesia) adalah ejaan bahasa Indonesia yang berlaku sejak tahun 2015 berdasarkan Peraturan Menteri Pendidikan dan Kebudayaan Republik Indonesia Nomor 50 Tahun 2015 tentang Pedoman Umum Ejaan Bahasa Indonesia. Ejaan ini menggantikan Ejaan yang Disempurnakan (EYD). Adanya peraturan ini, setiap mahasiswa yang memeroleh MKU Bahasa Indonesia dituntut harus bisa lulus dalam memahami dan menerapkannya EBI pada teks tulis. Namun, pada kenyataannya mahasiswa IT Telkom Purwokerto belum banyak yang tahu atau bahkan baru tahu mengenai PUEBI (pedoman umum ejaan bahasa Indonesia) ketika mengambil MKU Bahasa Indonesia.

Selain hal tersebut, ternyata tata tulis mereka pada surat dinas atau surat non dinas, makalah, dan laporan praktikum masih belum menerapkan PUEBI (pedoman umum ejaan bahasa Indonesia). Pada bagian isi surat, makalah, dan laporan praktikum mereka masih menggunakan ejaan yang lama dan menjadi kebiasaan di lingkungan kampus. Banyak dari para mahasiswa bersikap acuh tak acuh terhadap penggunaan ejaan bahasa Indonesia dalam menulis makalah dan laporan praktikum.

Ada beberapa pendapat para ahli mengenai makalah dan laporan praktikum. Makalah menurut E. Zaenal Arifin (2000:2) adalah karya tulis ilmiah yang menyajikan suatu masalah yang pembahasannya berdasarkan data di lapangan yang bersifat empiris - objektif. Selain itu ada definisi laporan, menurut Keraf (2001: 284) laporan adalah suatu cara komunikasi di mana penulis menyampaikan informasi kepada seseorang atau suatu badan karena tanggung jawab yang dibebankan kepadanya. Laporan berisi informasi yang didukung oleh data yang lengkap sesuai dengan fakta yang ditemukan. Data disusun sedemikian rupa sehingga akurasi informasi yang kita berikan dapat dipercaya dan mudah dipahami (Soegito dalam Wardani, 2008).

Sementara itu, Menurut Soekarno dkk (1990 : 14), metode praktikum adalah suatu cara mengajar yang memberi kesempatan kepada siswa untuk menemukan suatu fakta yang diperlukan atau ingin diketahuinya. Djamarah dan Zain (2002:95) memberi pengertian bahwa metode praktikum adalah proses pembelajaran dimana peserta didik melakukan dan mengalami sendiri, mengikuti proses, mengamati obyek, menganalisis, membuktikan dan menarik kesimpulan suatu obyek, keadaan dan proses dari materi yang dipelajari tentang gejala alam dan interaksinya sehingga dapat menjawab pertanyaan yang didapatkan melalui pengamatan induktif. Jadi laporan praktikum adalah informasi tertulis yang bersifat objektif dan faktual mengenai pengamatan suatu objek penelitian.

Selain pendapat dari para ahli tersebut, peneliti menemukan hal yang menarik untuk dianalisis, yaitu kesalahan penggunaan PUEBI (pedoman umum ejaan bahasa Indonesia) dan kesalahan penggunaan tata baku bahasa Indonesia. Kesalahan PUEBI meliputi pemakaian huruf, penggunaan kata, pemakaian tanda baca, dan penulisan kata serapan. Sementara itu, analisis kesalahan berbahasa merupakan suatu prosedur yang digunakan oleh peneliti maupun guru yang meliputi pengumpulan sampel, pengidentifikasian kesalahan yang terdapat dalam sampel, penjelasan kesalahan tersebut, pengklasifikasian kesalahan itu berdasarkan penyebabnya, serta pengevaluasian atau penilaian taraf keseriusan kesalahan itu (Ellis dalam Tarigan, 2011: 170). Pendapat lain dikemukakan oleh Musmulyadii (2016) ketika meneliti Kesalahan ejaan yang banyak ditemukan pada karangan pribadi siswa SMP Negeri 10 Poleang Selatan tahun ajaran 2015/2016, yaitu kesalahan penggunaan huruf kapital dimana terdapat 161 data kesalahan. Kesalahan pengunaan tanda baca,yaitu kesalahan penggunaan tanda titik dimana terdapat 42 data kesalahan, dan tanda koma terdapat 36 data kesalahan. Sementara itu, Tisnasari (2017) the results of this research are: 1) found 4 forms of error in the form, that is the basic form is not correct as much as $63 \%$, the form of repetition of compound word that is not exactly as $13 \%$, the form of sound that should be diluted but not melted as much as $13 \%$ Improper use of affixes of 8\%; 2) The lexical ability of students who write essays is good. However, there is a form error so that there is a mistake in the meaning.

Penelitian Johan (2018) kesalahan berbahasa Indonesia terletak pada kohesi dan koherensi yang ditemukan dalam proses diskusi siswa kelas VI SDN 1 Galagamba terdiri atas kesalahan penanda kata penghubung (konjungsi), kesalahan penyulihan (substitusi) dan kesalahan repetisi (pengulangan). Kesalahan logika yang ditemukan dalam proses diskusi siswa kelas VI SDN 1 Galagamba meliputi kesalahan kalimat yang tidak logis atau tidak dapat dinalar. Kemudian Nurwicaksono (2018) menemukan kesalahan pemakaian huruf mencapai 183 item atau 43,16\% dengan dominasi kesalahan pada pemakaian huruf miring, kesalahan penulisan kata mencapai 145 item atau 34,20\% dengan dominasi kesalahan pada penulisan kata berimbuhan awal di- dan kata depan di, kesalahan pemakaian tanda baca mencapai 68 item atau 16,04\% dengan dominasi kesalahan pada penggunaan spasi yang mubazir, dan kesalahan penulisan unsur serapan mencapai 28 item atau 6,6\% dengan dominasi kesalahan pada penulisan kosakata bahasa Indonesia yang diadaptasi dari bahasa Inggris dan Arab. Selain itu, menurut penelitian yang dilakukan Feny Oktaviani, dkk (2018) Ada banyak cara untuk menanggulangi kesalahan berbahasa yang terjadi, salah satunya adalah melalui analisis kesalahan berbahasa yang 
dilakukan oleh guru untuk mengetahui jenis kesalahan dan faktor penyebab kesalahan yang dilakukan oleh siswa.

Berdasarkan latar belakang tersebut, peneliti melakukan penelitian pada mahasiswa IT Telkom Purwokerto, yang kemudian diambil beberapa sampel untuk dianalisis guna mengetahui kesalahan penggunaan PUEBI dan kesalahan tata baku berbahasa Indonesia yang ada dalam makalah dan laporan praktikum mahasiswa. Adapun letak kesalahankesalahan penggunaan PUEBI dan kesalahan tata baku berbahasa Indonesia yang mereka lakukan dalam menulis laporan makalah dan laporan praktikum, misalnya: kesalahan penggunaan huruf, kata, tanda baca, dan kata serapan. Hal tersebut dapat digunakan sebagai umpan-balik dalam upaya memperbaiki dan menyempurnakan pengajaran bahasa Indonesia. Maka, analisis tersebut sangat penting untuk mengefektifkan pengajaran MKU bahasa Indonesia, yang difokuskan pada pembinaan kemampuan menulis mahasiswa.

\section{METODE}

Penelitian ini dilaksanakan di IT Telkom Purwokerto. Subjek penelitiannya yaitu Prodi S1 Teknik Telekomunikasi semester 2 kelas A dan B. Penelitian ini berupa penelitian deskriptif kualitatif pendekatan analisis isi dengan jenis penelitian studi kasus. Data dan sumber data yang digunakan dalam penelitian ini berupa dokumen dan informan dengan menggunakan teknik purposive sampling. Data dikumpulkan dengan cara mengkaji dokumen yang berupa makalah dan laporan hasil praktikum dan melakukan in-dept interview atau wawancara mendalam dengan beberapa mahasiswa, serta dosen teknik untuk memeroleh data mengenai faktor penyebab terjadinya kesalahan huruf, kata, tanda baca, dan kata serapan dalam makalah dan laporan praktikum mahasiswa. Selanjutnya, data divalidasi dengan menggunakan teknik triangulasi dan review informan melalui analisis interaktif yang terdiri atas empat tahap, yaitu: (1) pengumpulan data, (2) reduksi data, (3) penyajian data, dan (4) penarikan simpulan atau verifikasi.

\section{HASIL DAN PEMBAHASAN}

Hasil penelitian ini berupa analisis dan identifikasi jenis kesalahan-kesalahan penggunaan PUEBI dan tata baku berbahasa Indonesia yang ada dalam makalah dan laporan praktikum mahasiswa. Makalah dan laporan praktikum tersebut diidentifikasi berdasarkan jenis kesalahannya. Hasil identifikasi kesalahan-kesalahan ejaan yang diperoleh, kemudian diolah melalui teknik kerja analisis data. Data yang diperoleh dengan teknik membaca tiap kalimat dan mencatat kalimat yang ejaannya salah, kemudian dimasukkan dalam kartu data dan dianalisis dengan teknik deskripsi kualitatif. Kesalahan tersebut dibatasi dan diklasifikasikan ke dalam 4 bidang, yaitu huruf kapital dan miring, kata kata depan di, ke, dan antar, tanda baca, dan kata serapan.

Peneliti menemukan kesalahan berbahasa Indonesia dalam penelitian ini cukup banyak, yaitu sebanyak 247 kasus kesalahan, yang meliputi: (1) kesalahan pemakaian pemakaian huruf kapital dan miring berjumlah 8 kesalahan, (2) kesalahan kata depan $d i, k e$, dan antar berjumlah 30 kesalahan, (3) kesalahan penggunaan tanda baca berjumlah 209 kasus kesalahan dan (4) kesalahan penulisan unsur serapan tidak ditemukan kesalahan. Berikut ini tabel frekuensi dan persentase jenis kesalahan ejaan pada makalah dan laporan praktikum mahasiswa prodi Teknik Telekomunikasi IT Telkom Purwokerto.

Tabel 1 Persentase Jenis Kesalahan Ejaan pada Makalah dan Laporan Praktikum Mahasiswa Prodi Teknik Telekomunikasi IT Telkom Purwokerto

\begin{tabular}{|l|l|c|l|}
\hline No. & \multicolumn{1}{|c|}{ Aspek Kesalahan Ejaan } & Frekuensi & Persentase \\
\hline 1 & $\begin{array}{l}\text { Penggunaan huruf kapital dan } \\
\text { miring }\end{array}$ & 8 & $3,24 \%$ \\
\hline 2 & $\begin{array}{l}\text { Penulisan kata di, ke, dan } \\
\text { antar }\end{array}$ & 30 & $12,15 \%$ \\
\hline 3 & Penggunaan tanda baca & 209 & $84,61 \%$ \\
\hline 4 & Penulisan kata serapan & - & - \\
\hline \multicolumn{2}{|l}{ Jumlah } & 247 & $100 \%$ \\
\hline
\end{tabular}

Berikut beberapa kesalahan ejaan pada makalah dan laporan praktikum mahasiswa prodi Teknik Telekomunikasi IT Telkom Purwokerto.

\section{A. Kesalahan Penggunaan Huruf}

1. Kesalahan pada penulisan kata: LATAR BELAKANG Analisis penggunaan huruf kapital dalam kata LATAR BELAKANG tidak tepat. Huruf kapital yang tepat untuk menuliskan subjudul hanya pada huruf pertama semua kata, kecuali seperti kata di, ke, dari, dan, yang, dan untuk yang tidak terletak pada posisi awal. Sehingga menjadi

2. Kesalahan pada penulisan kalimat: Aplikasi big data terbaru telah diluncurkan oleh kaprodi S1 teknik telekomunikasi, dodi zulherman

Analisis penggunaan huruf pertama dalam kata kaprodi tidak tepat karena seharusnya kata yang memiliki unsur jabatan atau pangkat ditulis dengan huruf kapital pada awal kata. Kemudian kata dodi zuherman tidak tepat karena seharusnya kata yang berupa nama orang, panggilan, atau sapaan ditulis dengan huruf kapital pada awal kata, yaitu Kaprodi, Dodi Zulherman

3. Kesalahan pada penulisan kalimat: Kemajuan teknologi bangsa indonesia telah berkembang pesat

Analisis penggunaan huruf pertama pada kata indonesia tidak tepat karena seharusnya kata yang memiliki arti negara ditulis menggunakan huruf kapital pada awal kata, yaitu Indonesia.

4. Kesalahan pada penulisan kalimat: apabila laporan ini banyak sekali ditemukan kekurangan kami mohon maaf.

Analisis penggunaan huruf pertama pada kata apabila tidak tepat karena seharusnya kata yang terletak di awal kalimat harus menggunakan huruf kapital, yaitu Apabila. 
5. Kesalahan pada penulisan kalimat: Pelaksanaan praktikum pada hari selasa, 21 februari 2019.

Analisis penggunaan huruf pertama pada kata februari tidak tepat karena seharusnya kata yang memiliki arti bulan ditulis menggunakan huruf kapital di awal kata, yaitu Februari.

6. Kesalahan pada penulisan kalimat: Pembaruan big data dan IOT (Internet Of Things) dapat dilakukan

Analisis penggunaan huruf pada kata big dan IOT (Internet Of Things) tidak tepat karena kedua kata ini merupakan kata asing dari bahasa inggris yang menurut PUEBI harus ditulis dengan huruf miring, yaitu big data dan IOT (Internet Of Things)

7. Kesalahan pada penulisan kalimat: Kami mengajukan ijin praktik kepada Bapak.

Analisis penggunaan huruf pada kata ijin tidak tepat karena kata ini tidak baku sehingga kata yang baku adalah izin.

8. Kesalahan pada penulisan kalimat: Program studi tehnik telekomunikasi.

Analisis penggunaan huruf pada kata tehnik tidak tepat karena kata ini tidak baku sehingga kata yang baku adalah teknik.

\section{B. Kesalahan Penulisan Kata di, ke, dan antar}

1. Kesalahan kata pada penulisan kalimat: Hasil praktikum harus di buktikan secara menyeluruh. Analisisnya adalah penulisan kata di buktikan seharusnya tidak dipisah melainkan harus digabung karena tidak menunjukkan tempat sehingga menjadi dibuktikan

2. Kesalahan kata pada penulisan kalimat: semua kabel yang telah di masukkan kedalam pipa filter. Analisisnya adalah penulisan kata di masukkan tidak dipisah melainkan digabung karena tidak menunnjukkan tempat atau arah, kemudian kata kedalam seharusnya dipisah bukan digabung karena menunjukkan temapat atau arah sehingga menjadi dimasukkan ke dalam

3. Kesalahan kata pada penulisan kalimat: Di samping bermanfaat untuk meningkatkan kualitas teknologi Indonesia. Analisisnya adalah penulisan kata di samping tidak dipisah melainkan digabung karena tidak menunnjukkan tempat atau arah sehingga menjadi Disamping

4. Kesalahan kata pada penulisan kalimat: Jaringan telkom ini dapat mengakses antar desa dan antar kota. Analisisnya adalah seharusnya penulisan kata antar desa digabung bukan dipisah karena kata antar memberi makna "di antara lebih dari dua hal" sehingga menjadi antardesa dan antarkota
C. Kesalahan Penggunaan tanda baca

1. Tanda titik

- Saya mengucapkan terima kasih. Karena kerjasamanya selama ini

- A. Teknologi IOT Konsep dasar Tujuan

- Tabel 1. Persentase Kepuasan Pelanggan Telkom

- Kepada Yth Bapak Kaprodi

Penggunaan tanda baca (.) tersebut tidak tepat peletakannya, ada yang harus dihilangkan dan ditambah. Seharusnya seperti berikut ini.

- Saya mengucapkan terima kasih karena kerjasamanya selama ini. Tanda titik digunakan untuk mengakhiri pernyataan

- A. Teknologi IOT

Konsep dasar

Tujuan

Tanda titik dipakai di belakang angka atau huruf dalam suatu bagan, ikhtisar, atau daftar.

- Tabel 1 Persentase Kepuasan Pelanggan Telkom. Tanda titik tidak dipakai di belakang angka atau angka terakhir dalam penomoran deret digital yang lebih dari satu angka dalam judul tabel, bagan, grafik, atau gambar.

- Yth. Bapak Kaprodi. Tanda titik tidak dipakai di belakang (a) alamat penerima dan pengirim surat serta (b) tanggal surat.

2. Tanda Koma

- Telepon seluler, komputer atau internet yang dibutuhkan

- Teknologi itu sangat canggih tetapi, masyarakat belum siap menggunakannya

- Agar memiliki terobosan baru kita, harus mengembangkan SDM

- Mahasiswa dapat membuka internet kapan saja dan di mana saja. Oleh karena itu teknologi menjadi praktis dan efisien

Penggunaan tanda baca (,) tersebut tidak tepat peletakannya, ada yang harus dihilangkan dan ditambah. Seharusnya seperti berikut ini.

- Telepon seluler, komputer, atau internet yang dibutuhkan. Tanda koma dipakai di antara unsurunsur dalam suatu pemerincian atau pembilangan.

- Teknologi itu sangat canggih, tetapi masyarakat belum siap menggunakannya. Tanda koma dipakai sebelum kata penghubung, seperti tetapi, melainkan, dan sedangkan, dalam kalimat majemuk (setara).

- Agar memiliki terobosan baru, kita harus mengembangkan SDM. Tanda koma dipakai untuk memisahkan anak kalimat yang mendahului induk kalimatnya.

- Mahasiswa dapat membuka internet kapan saja dan di mana saja. Oleh karena itu, teknologi menjadi praktis dan efisien. Tanda koma dipakai di belakang kata atau ungkapan peng-hubung antarkalimat, seperti 
oleh karena itu, jadi, dengan demikian, sehubungan dengan itu, dan meskipun demikian.

3. Tanda titik koma

- Langkah-langkah praktikum meliputi

1.Sambungkan kabel input ke bagian output Function Generator

2.Atur frekuensi Function Generator ke $3 \mathrm{MHz}$

Penggunaan tanda baca titik koma (;) belum diletakkan. Seharusnya seperti berikut ini.

- Langkah-langkah praktikum meliputi

1.Sambungkan kabel input ke bagian output Function Generator;

2.Atur frekuensi Function Generator ke $3 \mathrm{MHz}$;

3.Melihat bentuk spektrum, hitung daya puncak sinyal ( $P$ max).

Tanda titik koma dipakai untuk memisahkan bagianbagian pemerincian dalam kalimat yang sudah menggunakan tanda koma.

4. Tanda hubung

- Data dari komputer dapat di back-up

- Aplikasi itu dapat di hack

Penggunaan tanda hubung tersebut tidak tepat karena salah meletekkan dan ada yang belum diberi tanda hubung. Seharusnya seperti ini.

- Data dari komputer dapat di-back up(kata dari bahasa inggris)

- Aplikasi itu dapat di-hack (kata dari bahasa inggris)

Tanda hubung dipakai untuk merangkai unsur bahasa Indonesia dengan unsur bahasa daerah atau bahasa asing.

\section{SIMPULAN}

Berdasarkan hasil penelitian menunjukkan bahwa masih ditemukan kesalahan ejaan pada pada makalah dan laporan praktikum mahasiswa Prodi Teknik Telekomunikasi IT Telkom Purwokerto. Jenis kesalahan ejaan yang sering dilakukan adalah huruf kapital dan miring, kata kata depan $d i, k e$, dan antar, tanda baca, dan kata serapan. sebanyak 247 kasus kesalahan, yang meliputi: (1) kesalahan pemakaian pemakaian huruf kapital dan miring berjumlah 8 kesalahan dengan persentase 3,24\%, (2) kesalahan kata depan di, ke, dan antar berjumlah 30 kesalahan dengan persentase $12,15 \%$, (3) kesalahan penggunaan tanda baca berjumlah 209 kasus kesalahan dengan persentase 84,61 \% dan (4) kesalahan penulisan unsur serapan tidak ditemukan kesalahan.

\section{DAFTAR PUSTAKA}

Arifin, E. Zaenal dan S. Amran Tasae. (2000). Cermat Berbahasa Indonesia. Jakarta: Akademi Presindo.

Badan Pengembangan dan Pembinaan Bahasa Kemendikbud. (2016). PUEBI (Pedoman Umum Ejaan Bahasa Indonesia). Jakarta: KDT (Katalog Dalam Terbitan).
Johan, G. M. (2018). Analisis Kesalahan Berbahasa Indonesia dalam Proses Diskusi Siswa Sekolah Dasar. Jurnal Pendidikan Bahasa dan Sastra, 18(1), 136-149.

Keraf, Gorys. (2001). Argumentasi dan Narasi. Jakarta: PT Gramedia Pustaka Utama.

Musmulyadi. (2016). Analisis Penggunaan Ejaan Yang Disempurnakan Pada Penulisan Karangan Pribadi Siswa Kelas VIIIA SMPN 10 Poleang Selatan. Jurnal Bastra. 4 (3), 1-17.

Nurwicaksono, B. D., \& Amelia, D. (2018). ANALISIS KESALAHAN BERBAHASA INDONESIA PADA TEKS ILMIAH MAHASISWA. AKSIS: Jurnal Pendidikan Bahasa dan Sastra Indonesia, 2(2), 138153.

Oktaviani, F., Rohmadi, M., \& Purwadi, P. (2018). Analisis Kesalahan Berbahasa Indonesia pada Karangan Eksposisi Siswa Kelas X MIPA (Studi Kasus di SMA Negeri 4 Surakarta). BASASTRA, 6(1), 94-109.

Soekarno. (1990). Teori Belajar. Jakarta: Depdikbud.

Syaiful Bahri Djamarah dan Aswan Zain. (2002). Strategi Belajar Mengajar. Jakarta: Rineka Cipta.

Tisnasari, Sundawati. (2017). Analysis of Language Errors on Build and Integrate Leksem Bahasa Indonesia. Jurnal Handayani. 7 (1), 28-37.

Prasetya, A. D. A. (2019). Analisis Kesalahan Ejaan dan Pilihan Kata pada Surat Dinas di STKIP Al Hikmah Surabaya. LINGUA FRANCA: Jurnal Bahasa, Sastra, dan Pengajarannya, 3(1), 120-127.

Tarigan, Henry Guntur. (2011). Pengajaran Analisis Kesalahan Berbahasa. Bandung: Penerbit Angkasa Bandung.

Tussolekha, R. (2019). Kesalahan Penggunaan Ejaan Bahasa Indonesia pada Makalah Karya Mahasiswa. AKSARA: Jurnal Bahasa dan Sastra, 20(1).

Wardhani, IGK. (2008). Penelitian Tindakan Kelas. Jakarta: Universitas Terbuka.

Wijayanti, Atrianing Yessi. (2016). “Analisis Kesalahan Penggunaan Ejaan Pada Skripsi Mahasiswa Program Studi di Pendidikan Guru Sekolah Dasar Fakultas Keguruan dan Ilmu Pendidikan Universitas Darul Ulum Islamic Centre Sudirman Guppi Undaris" dalam Jurnal Media Penelitian Pendidikan. 10 (2). 